\title{
Problems with Activity-Based Costing Implementation in Polish and Lithuanian Companies
}

\author{
Zaneta Pietrzak $^{1}$, Tomasz Wnuk-Pel², Ceslovas Christauskas ${ }^{3}$ \\ 1, 2 University of Lodz \\ 22/26 Matejki St., 90-237 Lodz, Poland \\ E-mail.'zaneta.pietrzak@uni.lodz.pl; ${ }^{2}$ tomasz.wnuk@uni.lodz.pl \\ ${ }^{2}$ Affiliated at Linnaeus University \\ Box 451, 35106 Vaxjo, Sweden \\ E-mail. ${ }^{2}$ tomasz.wnuk@uni.lodz.pl \\ ${ }^{3}$ Vytautas Magnus University \\ Universiteto 10-426, LT-53361, Akademija, Kauno r., Lithuania \\ E-mail. ${ }^{3}$ ceslovas.christauskas@gmail.com \\ cross $^{\text {ref }}$ http://dx.doi.org/10.5755/j01.ee.31.1.24339
}

\begin{abstract}
The research purpose was to examine the problems of companies in implementing Activity-Based Costing and, in particular, to analyze the differences in assessing the level of these problems perceived by organizations using the system, considering its implementation, those which had not considered it, and those which had rejected it. The research showed that the problems with ABC implementation seen by adopters were considerably smaller compared to the other groups. A similar difference was noted between enterprises that were considering the implementation of the ABC system (and not considering it at all) and those that rejected it. The last group perceived implementation problems to be bigger than was the case in the groups which were still considering implementation or had not considered it at all. The findings seem to support the view that companies are making ABC implementation decisions rationally. On the one hand, when the problems perceived during implementation are relatively small, the company adopts $A B C$. On the other hand, when a company perceives the implementation problems as being quite significant, it rejects the implementation. In the middle of the scale are companies considering the implementation of $A B C$ and others that are not thinking about it at all. They assess the perceived problems as moderate and are not in a position yet to decide for or against ABC implementation. There could also be an alternative explanation for the research results. It may be the case that companies, which have not implemented ABC overestimate the implementation problems.
\end{abstract}

Keywords: Activity-Based Costing; ABC; Problems with ABC Implementation; Survey; Poland; Lithuania.

\section{Introduction}

The benefits of Activity-Based Costing (ABC) for organizations which have implemented and are using the system are well known. According to Cooper \& Kaplan (1988), ABC can be used to support a corporate strategy, including strategic decisions such as pricing, product mix, new product designs, and the management of different resources (Innes \& Mitchel, 1995; Bescos et al., 2002; Allain \& Laurin, 2018; Altawati et al., 2018; Wegmann, 2019). The literature also shows situations where $\mathrm{ABC}$ is used in making operational decisions, such as: (a) reducing cost in operational departments (Anderson \& Young, 1999; Kujacic et al. 2015; Sorros et al., 2017), (b) improving quality (Innes \& Mitchel, 1995; Bescos et al., 2002; Feng \& Ho, 2016) and (c) modeling costs and value inventories (Innes \& Mitchel, 1995; Bescos et al., 2002; Kujacic et al. 2015; Almeida, Cunha, 2017). Since it originated in the late 1980s, the concept of ActivityBased Costing has been quite popular among organizations all over the world; however, $\mathrm{ABC}$ has also its well documented disadvantages. The most important seem to be: (a) collection of information for $\mathrm{ABC}$ is time-consuming and costly, (b) information delivered by $\mathrm{ABC}$ may be difficult to understand by managers, (c) ABC reports do not conform to generally accepted accounting principles and cannot be used for external reporting, (d) organizations are changing constantly which requires costly and time-consuming ABC modifications. ABC may not be useful for organizations with small share of indirect costs. It should also be borne in mind that implementing $\mathrm{ABC}$ is not easy. The implementation process is complex and requires many resources, which resulted in its relatively limited diffusion.

As the short analysis above shows there are potentially substantial benefits as well as problems connected with the decision whether to implement $\mathrm{ABC}$ or not. For some organizations the decision to implement could be a good solution and for others the good decision could be to reject implementation. This issue is very important from a microeconomic point of view as it is focused on the behaviour of an organization in making decisions which could influence both operational and strategic future of the organization. Studying this phenomena also requires applying general economic principles in analysing companies and specific problem inside those companies. In the case of this issue the 
research is addressing the question whether decisions about $\mathrm{ABC}$ implementation are rational in organizations and in other words whether organizations which perceive problems with implementation as small proceed with implementation and whether the ones that perceive problems as substantial, postpone or reject the implementation.

Although $\mathrm{ABC}$ has been known and used for 30 years, its relatively low diffusion makes it still an innovative technique. Moreover, as still a substantial percentage of organizations are considering its implementation, the problems with $\mathrm{ABC}$ implementation are relevant to these organizations.

The majority of studies on ABC carried out so far in Poland and Lithuania focused on determining the scope of $\mathrm{ABC}$ use, explaining the barriers and problems during its implementation only to a minor extent. There has not been enough research on perceived problems with $\mathrm{ABC}$ implementation separately in companies which have implemented $\mathrm{ABC}$, were considering its implementation, had never considered implementation, or which had rejected it. To address this research gap, the purpose of the study was to examine perceived problems with $\mathrm{ABC}$ implementation by those different groups of companies. We focused on checking whether companies which had adopted ABC assessed the problems of its implementation lower than companies which had rejected adoption after a cost-benefit analysis - it could mean that both groups made rational decisions. For the group of adopters, it could mean that the decision to implement was rational because the perceived problems (barriers) were not substantial and it was possible to implement $\mathrm{ABC}$ successfully. For the group of rejecters, it could also mean that the decision not to implement $\mathrm{ABC}$ was rational because the perceived problems (barriers) were high, which could potentially threaten a successful implementation. We also wanted to check if the other two groups of companies (considering or not considering implementation) would assess the problems (barriers) of ABC implementation not as low as the adopters but also not so high as the rejecters - and if such an assessment could mean that final decision of whether to implement $\mathrm{ABC}$ or reject it cannot yet be made in those companies. To the best of the authors' knowledge, such an extensive study on the topic in Poland and Lithuania has never been done before.

The original contribution of the research to the literature was threefold:

1. it examined perceived problems with $\mathrm{ABC}$ implementation in four different clusters of companies i.e. companies which: (a) implemented ABC, (b) were considering implementation, (c) were not considering implementation and (d) rejected implementation;

2. it showed significant differences in perceived problems with $\mathrm{ABC}$ implementation in the above four clusters of companies, proving rationality in decision making by managers of those companies as $\mathrm{ABC}$ implementation is concerned;

3. it confirmed that problems encountered in $\mathrm{ABC}$ implementation in Poland and Lithuania are similar to the problems in other countries.

Moreover, the research also has relevance for practitioners who could use its results to assess the magnitude of problems which they expect during $\mathrm{ABC}$ implementation - this could potentially help them make the right decision about whether to proceed with the implementation or not.
The rest of the paper is organized as follows. First, a short literature review is presented which is followed by a presentation of the research method. Next, the results are presented, followed by the discussion and conclusions.

\section{Literature Review}

The peak of Activity-Based Costing publications ended approximately 20 years ago, but $\mathrm{ABC}$ remains an important management accounting tool which is used by quite a few organizations all over the world. It is studied much less often than before, but $\mathrm{ABC}$ is still an interesting subject for research.

A number of studies conducted so far on Activity-Based Costing in different countries examined the barriers of its implementation and the problems encountered both during the implementation process and while using the system. Novak \& Popesco (2008) studied ABC diffusion in the Czech Republic found that the main barrier for implementation was a lack of experience and knowledge of ABC. Rundora \& Selesho's (2014) study on a sample of South African companies revealed that the main barriers for $\mathrm{ABC}$ diffusion were the lack of knowledge of $\mathrm{ABC}$, structural problems (identifying activities and cost drivers), financial constraints, or other priorities. According to the respondents, although the benefits of $\mathrm{ABC}$ were higher than the costs of its implementation, diffusion was low because of the perceived high implementation costs, the lack of IT resources, high labor input, the great detail of the system, and the lack of knowledge about ABC. The lack of interest in the ABC system was also studied by Clarke \& Mullins (2001), Askarany \& Yazdifar (2007), ElGammal et al. (2016), Quinn et al. (2017) and Hudakova \& Bajus (2015). All these studies indicated similar reasons for the slow diffusion of Activity-Based Costing, and the most frequently mentioned barriers to implementation included the high implementation and maintenance costs and insufficient knowledge of ABC among employees. The lack of IT resources and other priorities were indicated as barriers in a studies conducted by Askarany \& Yazdifar (2007), Quinn et al. (2017) and Allain \& Laurin (2018).

A small number of companies which were using ABC made other companies, which were considering its implementation, uncertain about the benefits of using Activity-Based Costing. Most studies have shown that companies considering ABC implementation were concerned about the expenses required to implement and maintain the system (its implementation is time-consuming, and involves the entire organization, staff training, and setting up a project team). The aspects related to the system design, e.g., the identification of activities, or the determination of cost drivers, especially in small firms, seemed problematic (Cohen et al., 2005; Sartorius et al., 2007; Allain, \& Laurin, 2018; Wahab et al., 2018). Akyol et al. (2005) claimed that appropriate IT resources constituted an important factor that influenced the success of ABC implementation. Staff resistance to change (Pierce \& Brown, 2004; Cohen et al., 2005; Quinn et al., 2017) and insufficient knowledge of ABC (Novak \& Popesco, 2008; Wegmann, 2011; Lu et al., 2016; Joseph \& Piorce, 2019) also caused concern among companies. One of the key factors that condition the success of $\mathrm{ABC}$ implementation is the 
understanding of the concept by employees at all levels; therefore, the implementation of this system must be accompanied by management's support and a training and promotion process (Daly \& Freeman, 1997). The lack of involvement and support from the board puts organizations at risk of wasting both effort and any chances of improving the company's competitiveness. Studying the implementation difficulties of Activity-Based Costing, Allain \& Laurin
(2018) found that attempting to use the costing system simultaneously in controlling and enabling ways may generate many difficulties related to the technical challenges faced while implementing and using the system, but also a lack of resources and resistance to change. A summary of the problems and barriers related to ABC implementation according to existing studies is presented in Table 1 .

Table 1

Problems and Barriers Related to the Implementation and Maintenance of ABC

\begin{tabular}{|l|l|}
\hline \multicolumn{1}{|c|}{ Problems and barriers } & \multicolumn{1}{c|}{ Authors } \\
\hline Lack of experience in terms of ABC & $\begin{array}{l}\text { Clarke et al. (1997), Groot (1999), Pierce \& Brown (2004), Askarany et al. (2007), Novak \& Popesco } \\
\text { (2008), Wegmann (2011), Rundora \& Selesho (2014), Wegmann, G. (2019) }\end{array}$ \\
\hline $\begin{array}{l}\text { System structuring (identification of } \\
\text { activities, cost pools, cost drivers) }\end{array}$ & $\begin{array}{l}\text { Clarke et al. (1997), Groot (1999), Horngren et al. (2000), Pierce \& Brown (2004), Cohen et al. (2005), } \\
\text { Sartorius et al. (2007), Rundora \& Selesho (2014); Wahab et al. (2018) }\end{array}$ \\
\hline Inadequate computer software & Clarke et al. (1997), Cohen et al. (2005), Jinga et al. (2010), Rundora \& Selesho (2014) \\
\hline Lack of resources, financial constraints & Clarke et al. (1997), Anderson \& Young (1999), Wegmann (2011), Rundora \& Selesho (2014) \\
\hline Resistance of staff, reluctance to change & Anderson \& Young (1999), Pierce \& Brown (2004), Cohen et al. (2005), Dragija \& Lutisky (2012) \\
\hline $\begin{array}{l}\text { Other priorities (e.g., ISO, ERP } \\
\text { implementation) }\end{array}$ & Groot (1999), Askarany et al. (2007), Rundora \& Selesho (2014) \\
\hline $\begin{array}{l}\text { Management's lack of interest and } \\
\text { support }\end{array}$ & Horngren et al. (2000), Cohen et al. (2005), Jinga et al. (2010) \\
\hline Lack of software & Pierce \& Brown (2004), Cohen et al. (2005), Askarany et al. (2007), Wahab et al. (2018) \\
\hline Satisfaction with existing system & $\begin{array}{l}\text { Pierce \& Brown (2004), Cohen et al. (2005), Jinga et al. (2010), Wegmann (2011), Dragija \& Lutisky } \\
\text { (2012), Arora \& Raju (2018) }\end{array}$ \\
\hline $\begin{array}{l}\text { High costs of implementation and } \\
\text { maintenance }\end{array}$ & $\begin{array}{l}\text { Cohen et al. (2005), Askarany et al. (2007), Jinga et al. (2010), Rundora \& Selesho (2014), Arora \& Raju } \\
\text { (2018) }\end{array}$ \\
\hline Perceiving ABC as complicated & Pierce \& Brown (2004) \\
\hline
\end{tabular}

Source: Miodek \& Wnuk-Pel, 2017.

The first evidence of Activity-Based Costing use in Poland was found by Sobanska \& Wnuk (2000), Szychta (2002) and Januszewski \& Gierusz (2004). Research which appeared several years later showed that $\mathrm{ABC}$ had been applied in about $10 \%$ of companies (Dynowska \& Cyganska, 2010; Wnuk-Pel, 2011). The latest research on ABC diffusion by Miodek \& Wnuk-Pel (2017) showed greater diffusion of $\mathrm{ABC}$ (14\% used $\mathrm{ABC}, 27 \%$ used certain elements of the system, and $2 \%$ were in the process of implementing it). Lithuanian research on ABC was less frequent than studies done in Poland. They were mainly performed at the beginning of the $21^{\text {st }}$ century and focused on both the diffusion of Activity-Based Costing (Valanciene \& Gimzauskiene, 2007; Strumickas \& Valanciene, 2009), factors influencing its diffusion (Gliaubicas \& Kanapickiene, 2015) or the role of organizational values on ABC implementation (Gimzauskiene \& Kloviene, 2008).

There were also research in Poland and Lithuania which, to some extent, examined the barriers to ActivityBased Costing implementation. Januszewski \& Gierusz's (2004) research identified the most frequently mentioned barriers to $\mathrm{ABC}$ implementation: the satisfaction of the management board with information about costs, a lack of expertise and resources, and the resistance of staff. The reasons for abandoning Activity-Based Costing in the surveyed companies included high implementation costs, high-labor input, lack of sufficient knowledge, lack of support from the management, and lack of appropriate software. The companies which had never considered implementing $\mathrm{ABC}$ provided the following arguments: satisfaction with the current system, lack of sufficient knowledge of $\mathrm{ABC}$, and financial restraints. The survey by
Dynowska \& Cyganska (2010) found that companies that were planning to implement $\mathrm{ABC}$ in the future indicated huge labor input related to implementing and maintaining the system, insufficient knowledge of $\mathrm{ABC}$, and difficulties in developing a model. On the other hand, companies which had never planned to implement $\mathrm{ABC}$ mentioned barriers such as satisfaction with the existing system, insufficient knowledge of Activity-Based Costing, and low indirect costs.

Another study on the use of $\mathrm{ABC}$ was performed by Wnuk-Pel (2011). He found that the lack of interest in the $\mathrm{ABC}$ system and the rejection of its implementation were justified by insufficient knowledge among employees, high labor input in the implementation and maintenance of ABC, the high costs of implementation, and a lack of computer software. The main problems expected by companies which were considering Activity-Based Costing implementation included insufficient knowledge of $\mathrm{ABC}$ among employees, high labor input during implementation, and problems with model construction. As far as problems with implementing $\mathrm{ABC}$ are concerned, the respondents most frequently mentioned insufficient knowledge of ABC among employees, problems with model construction, and lack of computer software. None of these problems was identified as very significant; the majority of problems were rated as moderate or small.

A review of the literature on barriers to and problems with Activity-Based Costing implementation revealed that there is a lack of comprehensive, cross-country research on problems with $\mathrm{ABC}$ that takes different types of company separately, i.e., those which: (a) had implemented ABC, (b) were considering its implementation, (c) had never considered its implementation, and (d) had rejected 
implementation after a cost-benefit analysis. In particular, there is a lack of research surveying the same size of companies, the types of measures, or the phraseology of the questioning. To address this research gap we attempted to employ the same research instrument and administrative procedures and to compare samples matched by company size.

In light of the above, the purpose of the research was to examine the perceived problems with $\mathrm{ABC}$ implementation of Polish and Lithuanian companies. To achieve this aim, we tried to answer two research questions:

1. What are the most important problems of implementing $\mathrm{ABC}$ in companies which had implemented $\mathrm{ABC}$, were considering its implementation, had never considered its implementation or which had rejected it?

2. Are the problems of $\mathrm{ABC}$ implementation the highest in companies which had rejected implementation, relatively smaller in companies considering or which had not considered implementation, and the smallest in companies which had implemented the system?

As we focused on a detailed observation of the contextual factors that influence $\mathrm{ABC}$ implementation, our research is mainly descriptive.

\section{Research Method}

We selected the survey research method to address the research questions despite its well-known shortcomings. We were convinced that it would facilitate comparisons of company practice in Poland and Lithuania in terms of ABC implementation, and could contribute to modifying existing beliefs on the factors that influence the implementation process. What is more, our intention was to compare the results with research conducted in other countries (Askarany et al., 2007; Jinga et al., 2010; Wegmann, 2011; Dragija \& Lutisky, 2012; Rundora \& Selesho, 2014; Quinn et al., 2017). To the best of our knowledge, such a broad and comprehensive overview of $\mathrm{ABC}$ practice has never been performed in Polish or Lithuanian companies before.

To analyze problems with $\mathrm{ABC}$ implementation in Polish and Lithuanian companies, the respondents were asked seven groups of questions related to (see Appendix 1):

- the company's characteristics (6 questions),

- the chief financial officer's characteristics (3 questions),

- general information about the company's costing system (4 questions),

- factors influencing $\mathrm{ABC}$ use in companies which had implemented ABC (15 questions),

- problems encountered in the process of implementing $\mathrm{ABC}$ in companies which had implemented $\mathrm{ABC}$ (8 questions),

- expected problems when implementing $A B C$ in companies which were considering its implementation (8 questions),

- problems expected in the process of implementing $\mathrm{ABC}$ in companies which were not considering its implementation or which had rejected it (10 questions).

The questionnaire contained one-choice questions, but the respondents were asked to provide more expansive answers and comments. In the questions about perceived problems with $\mathrm{ABC}$ implementation (question: 4.2, 4.3, 4.4 and 4.5; Appendix 1), a five-point Likert scale was used. The authors first pretested the questionnaire on fellow colleagues at their faculties to establish content validity (Zikmund et al., 2003). After slight corrections, it was tested again on a small group of practitioners in both countries, which was followed by additional minor corrections and improvements. We decided not to distribute the questionnaire by e-mail or traditional mail as the response rate in this kind of distribution in Poland and Lithuania is extremely low (often far below 1\%). So, the questionnaires were distributed among management accountants participating in postgraduate studies and courses in the area of management accounting. Thus, tests for non-response bias were not run as it was impossible to compare early and late respondents. The sample was limited to medium, large, and very large organizations; small companies (defined by the European Union Commission Recommendation of 6 May 2003) employing fewer than 50 people were excluded from the sample as, generally, the formal use of different management accounting tools in those organizations is limited. Data collection started in November 2018 and ended in April 2019. In total, 423 questionnaires were distributed in Poland and 97 in Lithuania. Two hundred twenty-eight properly completed questionnaires were received in Poland and 45 in Lithuania, after leaving out incomplete questionnaires. Thus, the response rate was $52.50 \%$ (53.90 \% in Poland and $46.39 \%$ in Lithuania). In total, 273 samples were used in the study.

Nonparametric tests were used during the analysis. This is due to the failure to meet the assumptions for parametric tests: using the ordinal scale (respondents' rating in the range of 1-5) and different numbers in individual groups (countries). Due to the fact that the choice of the sample was non-random, the findings of the research cannot be generalized to all companies within the investigated population.

While preparing and conducting the survey, the authors undertook numerous activities to ensure the structural reliability of the research, internal and external reliability, as well as the validity of the study. The activities may be summarized as follows: (a) structural reliability - the conducted research was preceded by extensive literature studies, which enabled the choice of appropriate concepts and research methods for the analyzed phenomenon, (b) internal reliability - in order to maintain the internal reliability of the research, we ensured that the respondents who answered the questionnaire had knowledge of the analyzed phenomenon, i.e., the functioning of ActivityBased Costing, and perceived problems with $\mathrm{ABC}$ implementation, (c) external reliability - in order to maintain external reliability, the results of the research were compared to the results obtained by other authors (from Poland, Lithuania and other countries), (d) validity - to ensure the validity of the study, appropriate procedures and means of storing data were established prior to the research.

\section{Research Results}

\section{General Description of the Companies Covered by the Survey}

The survey respondents represented 273 companies, of which 228 were from Poland (i.e., $83.5 \%$ of the sample) and 
45 from Lithuania $(16.5 \%)$. They came both from the manufacturing and non-manufacturing sectors, with a predominance of non-manufacturing firms $(57.6 \%)$. The percentage of non-manufacturing companies in the sample was similar in Poland (55.8\%) and Lithuania (66.7 \%), with manufacturing firms making up $42.4 \%$ of the sample (44.2 $\%$ in Poland and $33.3 \%$ in Lithuania). The vast majority of the companies $(69.0 \%)$ came from the private sector, while only $31.0 \%$ were associated with the public sector. This division was similar in both countries. Regarding the source of equity capital in the companies, there was only domestic capital in $51.1 \%$ of the companies; a similar proportion (48.9\%) had mixed capital - partly domestic and partly foreign. The variable for the number of employees used to define the size of the companies in this research is presented in Table 2.

Table 2

The Number of Employees in the Companies Surveyed

\begin{tabular}{|c|c|c|c|c|c|c|}
\hline \multirow{2}{*}{ Specification } & \multicolumn{2}{|c|}{ Total } & \multicolumn{2}{|c|}{ Poland } & \multicolumn{2}{|c|}{ Lithuania } \\
\hline & $\mathbf{N}$ & $\%$ & $\mathbf{n}$ & $\%$ & $\mathbf{n}$ & $\%$ \\
\hline No data & 1 & 0.4 & 1 & 0.4 & & \\
\hline 51-250 employees & 112 & 41.0 & 90 & 39.5 & 22 & 48.9 \\
\hline $251-1000$ employees & 87 & 31.9 & 73 & 32.0 & 14 & 31.1 \\
\hline More than 1000 employees & 73 & 26.7 & 64 & 28.1 & 9 & 20.0 \\
\hline Total & 273 & 100.0 & 228 & 100.0 & 45 & 100.0 \\
\hline
\end{tabular}

Taking into account the number of employees, three categories of companies were distinguished: medium, large, and very large (small entities with fewer than 50 employees were not examined in the survey). Medium-sized entities (51-250 employees) proved to be the dominant group (41.0 $\%)$ - both in Poland (39.5 \%) and in Lithuania (48.9 \%), compared to $31.9 \%$ for large (251-1000 employees) and $26.7 \%$ for very large entities (more than 1000 employees). It is worth noting that in the surveyed group, medium-sized entities predominate both in terms of revenues $34.8 \%$ of enterprises were characterized by revenues between $€ 11$ and 50 million, larger units comprised $16.1 \%$ and $18.7 \%$ of the sample in Poland and Lithuania, respectively) and assets (23.4\% enterprises had total assets between $€ 11$ and 43 million; larger units comprised $16.8 \%$ and $14.6 \%$ of the sample in Poland and Lithuania, respectively).

\section{Characteristics of the Cost Accounting Systems used in the Companies}

The findings of the survey suggest that the actual shape of the costing systems currently used in these enterprises was set independently by the company's management in more than one-third of the cases ( $35 \%$ ). In $32.5 \%$ of the surveyed companies, it depended on the head office (e.g., the parent company) and in $29.2 \%$ it was determined in part by the management and in part by the headquarters. The remaining respondents $(3.2 \%)$ indicated a different form of decision. This distribution is close to the situation of the Polish enterprises but slightly different in Lithuania, where the shape of the company's costing system was decided almost entirely by the headquarters (38.1\%), partly by the company's management and by the headquarters $(33.3 \%)$, independently by the company's management $(23.8 \%)$, and other $(4.8 \%)$.
Regarding when the existing costing systems were implemented, there are considerable differences among the sample enterprises. Most companies (48.7\%) had implemented a costing system four to ten years earlier, and in $33.0 \%$ of the companies, the cost accounting systems were "older" than ten years. Only in $18.3 \%$ of the sample companies relatively "younger" costing systems were used - they had been implemented less than three years before. In as many as $81.7 \%$ of companies, the costing systems used had been functioning for more than three years.

In the majority of the companies surveyed, the proportion of indirect costs in total costs grew over the last ten years. In $20.7 \%$ of the enterprises, no change in the proportion of indirect costs was observed, and in $6.9 \%$ it was reported to have decreased. In the majority of enterprises $(40.1 \%)$, the share of indirect costs was low: under $10 \%(10.0 \%)$ and between 10 and $20 \%$ (30.1\%). However, a large number of enterprises estimated it at a higher level: $21-30 \%$ in $23.1 \%$ of companies, $31-40 \%$ in $21.6 \%$ of companies and more than $40 \%$ in $15.2 \%$ of companies. It is worth mentioning that the share of indirect costs is higher in Poland than in Lithuania.

\section{Problems with ABC implementation}

The first question in the main section of the questionnaire examined companies' attitudes towards ABC. The answers to this question was the basis for dividing the enterprises into four groups, which are presented in Table 3: Group A - companies using ABC, Group B - companies considering the implementation of $\mathrm{ABC}$ in the future, Group $\mathrm{C}$ - companies which has not yet considered implementing $\mathrm{ABC}$, and Group D - companies which has examined the possibility of $\mathrm{ABC}$ implementation but rejected it.

Table 3

Characteristics of the Distinguished Groups

\begin{tabular}{|c|c|c|c|c|}
\hline & Group & $\%$ & $\%$ & Cumulative \% \\
\hline A & companies using $\mathrm{ABC}$ & 21.5 & \multirow{2}{*}{42.6} & 21.5 \\
\hline B & companies considering $\mathrm{ABC}$ use & 21.1 & & 42.6 \\
\hline $\mathrm{C}$ & companies which didn't consider ABC use & 52.5 & \multirow{2}{*}{57.4} & 95.1 \\
\hline $\mathrm{D}$ & companies which rejected $\mathrm{ABC}$ & 4.9 & & 100.0 \\
\hline & Total & 100.00 & & \\
\hline
\end{tabular}

The majority of companies $(52.5 \%)$ had not considered adopting ABC, while $4.9 \%$ had considered its adoption but

decided against it. $21.5 \%$ of the entities had implemented $\mathrm{ABC}$, and $21.1 \%$ were considering its adoption. 
As the research attempted to identify and compare problems envisaged by companies in 4 separated groups, the next question was aimed at evaluating the importance of problems related to $\mathrm{ABC}$ implementation: (a) lack of management support, (b) the high cost of $\mathrm{ABC}$ implementation and operation, (c) high labour input in $\mathrm{ABC}$ implementation and operation, (d) other priorities (e.g. implementation of ISO, ERP), (e) insufficient knowledge of ABC among employees, (f) difficulty with model construction (i.e. selection of activities), (g) lack of adequate
IT resources, and (h) other. Based on the responses, an index was developed. This index $\left(\mathrm{IND}_{\mathrm{X}}\right)$ was calculated as the average rating (respondent's evaluation from 1 to 5) for all the analyzed aspects for each selected group.

Panel A in Table 4 presents the characteristics of the separate groups (A, B, C, and D) calculated on the basis of the indices developed. The last line shows the index (IND) calculated for all enterprises, regardless of the group. For more detailed analysis, the groups in the cross-section of countries were also presented (Panels B and C in Table 4).

Characteristics of the Index for the Groups A, B, C and D

Table 4

Panel A - total

\begin{tabular}{|l|c|c|c|c|c|c|c|c|}
\hline & Mean & Median & Mode & Mode $(\mathbf{N})$ & Min & Max & Standard deviation & Coefficient of variability \\
\hline $\mathrm{IND}_{\mathrm{A}}$ & 2.5 & 2.6 & 3 & 5 & 1.0 & 4.5 & 0.7 \\
\hline $\mathrm{IND}_{\mathrm{B}}$ & 3.0 & 3.0 & 3 & 6 & 1.6 & 4.4 & 29.3 \\
\hline $\mathrm{IND}_{\mathrm{C}}$ & 3.1 & 3.1 & - & 7 & 1.0 & 5.0 & 0.7 & 1.0 \\
\hline $\mathrm{IND}_{\mathrm{D}}$ & 3.6 & 3.4 & - & 2 & 2.7 & 4.3 & 3.3 & 0.6 \\
\hline $\mathrm{IND}$ & 3.0 & 3.0 & 3 & 18 & 1.0 & 5.0 & 0.9 & 30.0 \\
\hline
\end{tabular}

Panel B - Poland

\begin{tabular}{|c|c|c|c|c|c|c|c|c|}
\hline & Mean & Median & Mode & Mode (N) & Min & Max & Standard deviation & Coefficient of variability \\
\hline $\mathrm{IND}_{\mathrm{A}}$ & 2.5 & 2.4 & 2 & 4 & 1.0 & 4.5 & 0.8 & 30.2 \\
\hline $\mathrm{IND}_{\mathrm{B}}$ & 3.0 & 3.0 & - & 5 & 1.6 & 4.4 & 0.7 & 23.2 \\
\hline $\mathrm{IND}_{\mathrm{C}}$ & 3.1 & 3.1 & - & 5 & 1.0 & 5.0 & 1.1 & 34.3 \\
\hline $\mathrm{IND}_{\mathrm{D}}$ & 3.6 & 3.4 & 3.4 & 2 & 2.7 & 4.3 & 0.6 & 16.7 \\
\hline IND & 3.0 & 3.0 & 2.4 & 12 & 1.0 & 5.0 & 0.9 & 31.2 \\
\hline
\end{tabular}

Panel C - Lithuania

\begin{tabular}{|l|c|c|c|c|c|c|c|c|}
\hline & Mean & Median & Mode & Mode $(\mathbf{N})$ & Min & Max & Standard deviation & Coefficient of variability \\
\hline IND $_{\mathrm{A}}$ & 2.5 & 2.7 & - & 2 & 1.0 & 3.0 & 0.7 \\
\hline $\mathrm{IND}_{\mathrm{B}}$ & 2.9 & 3.1 & 3.4 & 2 & 1.9 & 3.6 & 0.7 \\
\hline $\mathrm{IND}_{\mathrm{C}}$ & 3.2 & 3.1 & 3.7 & 5 & 1.1 & 5.0 & 27.8 \\
\hline $\mathrm{IND}_{\mathrm{D}}$ & 3.6 & 3.6 & - & 1 & 3.0 & 4.3 & 0.8 & 0.9 \\
\hline $\mathrm{IND}$ & 3.0 & 3.0 & 3 & 7 & 1.0 & 5.0 & 24.8 & 0.8 \\
\hline
\end{tabular}

The indices developed do not show differences in individual countries (the U Mann-Whitney test was used); therefore, further analysis was made jointly for both Polish and Lithuanian companies.

Companies using the $\mathrm{ABC}$ system (group $\mathrm{A}$ ) rated the main problems during implementation the lowest (the average was 2.5 , lower than the average in the entire sample). None of the problems listed in the survey questionnaire was assessed as significant or very significant (Table 5, Panel A). Three problems were regarded as moderate (from 2.5 to 3.0 points): high labor input in $\mathrm{ABC}$ implementation and operation, difficulty with model construction, and insufficient knowledge of ABC among employees. Other problems were evaluated as insignificant (from 1.6 to 2.4 points).

Companies which were considering using $\mathrm{ABC}$ in the future (Group B) rated the problems perceived during $\mathrm{ABC}$ implementation as average: 3.0. The main potential problems (regarded as significant) expected during ABC adoption were (Table 5, Panel B): (a) insufficient knowledge of ABC among employees (average rating: 3.7 ) and (b) other - the problems cited here by the respondents include telecommunications law and energy law requirements, corporate directives, implementation of an ERP, fear of innovation, and lack of materials addressing $\mathrm{ABC}$ implementation in their particular industry (average rating: 3.5). There were five potential problems regarded as moderately significant (rated from 2.9 to 3.4), and only one (other priorities) was regarded as insignificant.

A similar assessment was obtained in the case of problems envisaged by companies which had never considered adopting ABC (group C); the average in this group was 3.1 (Table 5, Panel C). The respondents identified and assessed the strength of individual problems, and the most important (significant) was insufficient knowledge of $\mathrm{ABC}$ among employees (average rating: 3.5). All the other seven problems were perceived as moderately significant (with a rating from 2.7 to 3.4 ).

The last group (D) was characterized by the highest level of expected problems (average rating: 3.6). The respondents from this group examined the possibility of $\mathrm{ABC}$ implementation and rejected it because they predicted problems connected with it were too high (Table 5, Panel D). There was two reasons regarded as very significant among respondents in this group (high labor input in $\mathrm{ABC}$ implementation and operation, and high cost of $\mathrm{ABC}$ implementation and operation) and three reasons with significance assessed as more than average (difficulty with model construction (i.e. activities selection), lack of adequate IT resources and lack of management support). 
Main Problems during ABC Implementation

Panel A - companies using ABC system
\begin{tabular}{|l|c|c|c|c|c|}
\hline & $\mathbf{N}^{\mathbf{a}}$ & Mean & Mode & Standard deviation & Coefficient of variability \\
\hline lack of management support & 36 & 1.6 & 1 & 0.9 & 52.9 \\
\hline high cost of ABC implementation and operation & 35 & 2.2 & 2 & 0.8 & 36.2 \\
\hline high labor input in ABC implementation and operation & 37 & 3.0 & 3 & 1.1 & 35.1 \\
\hline other priorities (e.g. implementation of ISO, ERP) & 34 & 2.3 & 1 & 1.1 & 49.8 \\
\hline insufficient knowledge of ABC among employees & 37 & 2.8 & 3 & 0.9 & 34.4 \\
\hline $\begin{array}{l}\text { difficulty with model construction (i.e. activities } \\
\text { selection) }\end{array}$ & 33 & 2.9 & 3 & \multirow{2}{*}{1.2} & 41.7 \\
\hline lack of adequate IT resources & 33 & 2.4 & - & 1.2 & 51.6 \\
\hline other & 2 & 2.5 & - & 2.1 & 84.8 \\
\hline
\end{tabular}

Panel B - companies considering ABC adoption

\begin{tabular}{|l|c|c|c|c|c|}
\hline & $\mathbf{N}^{\mathbf{a}}$ & Mean & Mode & Standard deviation & Coefficient of variability \\
\hline lack of management support & 46 & 2.9 & 1 & 1.2 & 62,4 \\
\hline high cost of ABC implementation and operation & 46 & 3.1 & 2 & 1,0 & 33.3 \\
\hline high labor input in ABC implementation and operation & 46 & 3.4 & 4 & 1.0 & 28.9 \\
\hline other priorities (e.g. implementation of ISO, ERP) & 44 & 2.4 & - & 1,3 & 52.9 \\
\hline insufficient knowledge of ABC among employees & 46 & 3.7 & 4 & 1.0 & 26.1 \\
\hline $\begin{array}{l}\text { difficulty with model construction (i.e. activities } \\
\text { selection) }\end{array}$ & 46 & 3.3 & 3 & 0,9 & 29.1 \\
\hline lack of adequate IT resources & 45 & 3.3 & 5 & 1,4 & 41.3 \\
\hline other & 4 & 3.5 & 4 & 1,7 & 49.5 \\
\hline
\end{tabular}

Panel C - companies not considering ABC adoption

\begin{tabular}{|c|c|c|c|c|c|}
\hline & $\mathbf{N}^{\mathbf{a}}$ & Mean & Mode & Standard deviation & Coefficient of variability \\
\hline lack of management support & 83 & 3.4 & - & 1.4 & 40.7 \\
\hline high cost of $\mathrm{ABC}$ implementation and operation & 83 & 2,7 & 1 & 1.3 & 48.5 \\
\hline high labor input in $\mathrm{ABC}$ implementation and operation & 82 & 3.1 & 4 & 1.4 & 45.3 \\
\hline other priorities (e.g. implementation of ISO, ERP) & 85 & 2.7 & 1 & 1.5 & 54.0 \\
\hline insufficient knowledge of $\mathrm{ABC}$ among employees & 85 & 3.5 & 4 & 1.2 & 34.7 \\
\hline $\begin{array}{l}\text { difficulty with model construction (i.e. activities } \\
\text { selection) }\end{array}$ & 82 & 3.1 & 4 & 1.3 & 41.6 \\
\hline lack of adequate IT resources & 82 & 2.8 & - & 1.4 & 48.0 \\
\hline other & 5 & 2.8 & 1 & 1.8 & 63.9 \\
\hline
\end{tabular}

Panel D - companies not considering or rejecting $A B C$

\begin{tabular}{|c|c|c|c|c|c|}
\hline & $\mathbf{N}^{\mathbf{a}}$ & Mean & Mode & Standard deviation & Coefficient of variability \\
\hline lack of management support & 8 & 3.5 & 3.5 & 0.5 & 15.3 \\
\hline high cost of $\mathrm{ABC}$ implementation and operation & 9 & 4.3 & 5 & 0.9 & 20.0 \\
\hline high labor input in $\mathrm{ABC}$ implementation and operation & 9 & 4.4 & 5 & 0.7 & 16.3 \\
\hline other priorities (e.g. implementation of ISO, ERP) & 9 & 2.8 & 5 & 1.5 & 53.3 \\
\hline insufficient knowledge of ABC among employees & 9 & 2.9 & 3 & 1.1 & 36.5 \\
\hline $\begin{array}{l}\text { difficulty with model construction (i.e. activities } \\
\text { selection) }\end{array}$ & 9 & 3.7 & 4 & 1.2 & 33.4 \\
\hline lack of adequate IT resources & 9 & 3.7 & 4 & 1.0 & 27.3 \\
\hline other & 1 & 5.0 & 5 & & \\
\hline
\end{tabular}

${ }^{a}$ The respondents assessed the significance of problems according to the following scale: 1 - no problem, 2 - insignificant, 3 - moderately significant, 4 - significant, 5 - very significant.

The differences in assessing problems with $\mathrm{ABC}$ implementation perceived by companies using the system, those considering its use in the future, those not considering its implementation at all, and also companies which had rejected the system are shown graphically in Figures 1 (generally) and 2 (in detail). 
Zaneta Pietrzak, Tomasz Wnuk-Pel, Ceslovas Christauskas. Problems with Activity-Based Costing Implementation in ...

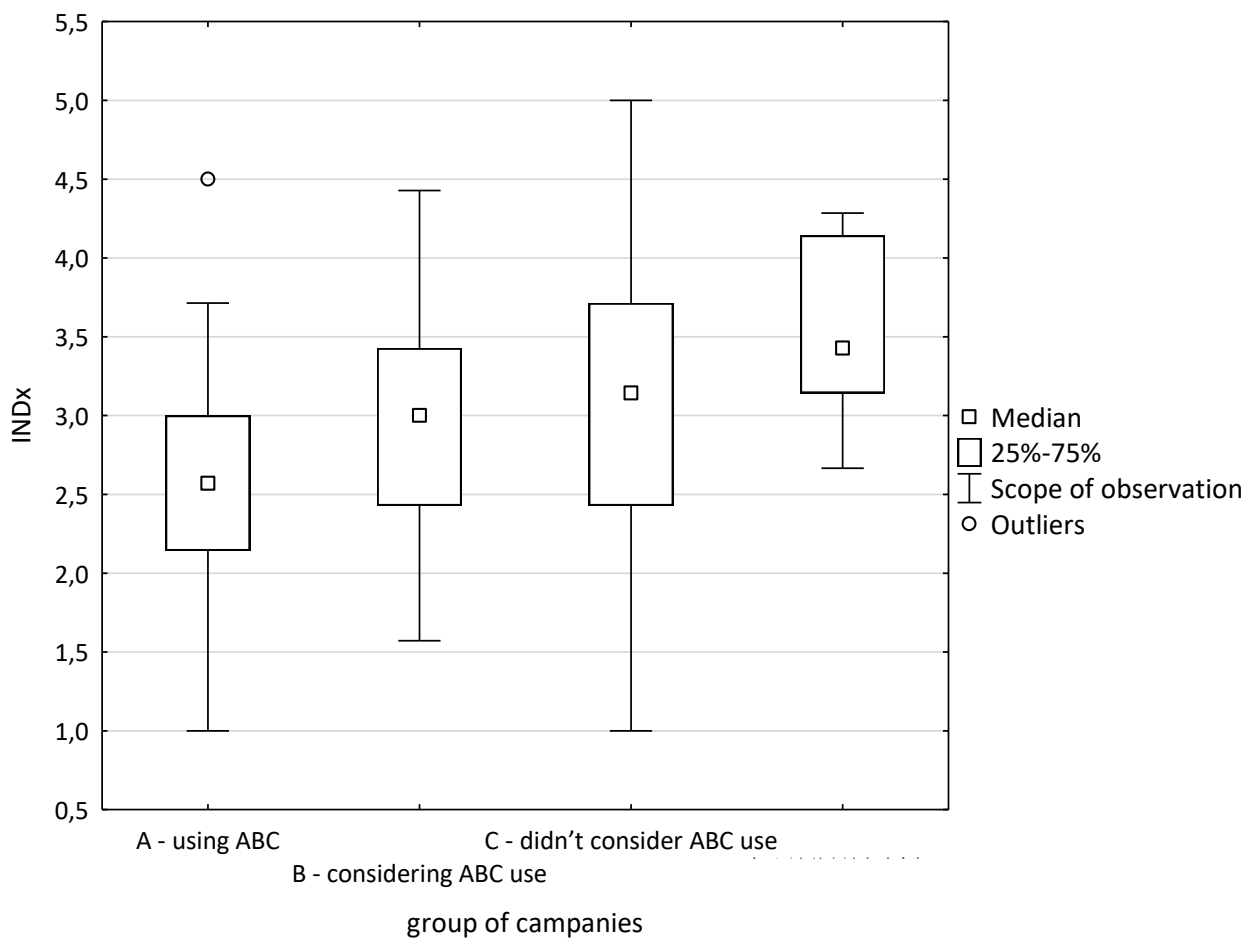

Figure 1. Median of the Developed Index (INDx) for the Selected Group of Companies

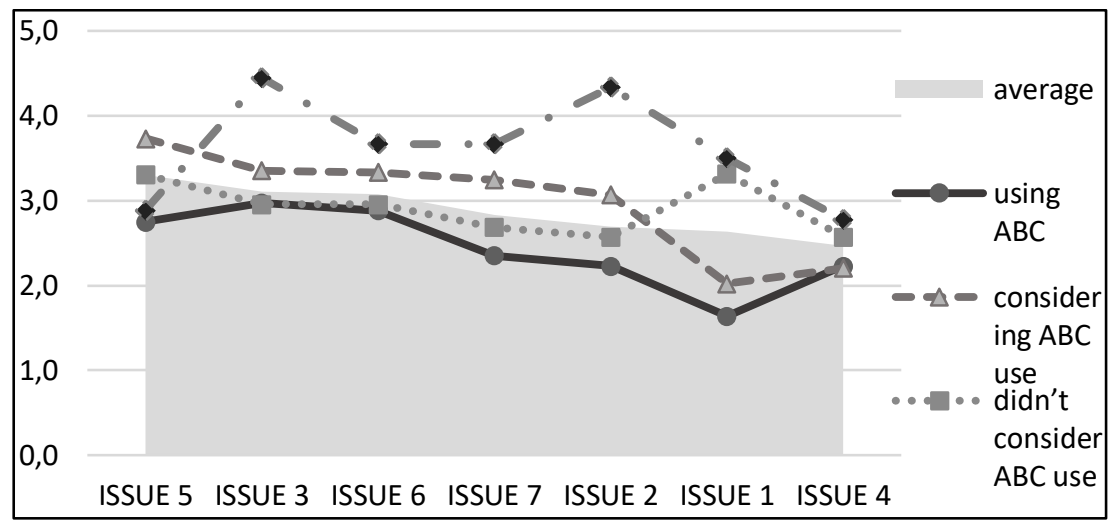

Figure 2. Problems with ABC Implementation in Four Selected Groups of Companies

Where: ISSUE 1 - lack of management support; ISSUE 2 - high cost of ABC implementation and operation; ISSUE 3 - high labor input in ABC implementation and operation; ISSUE 4 - other priorities (e.g. implementation of ISO, ERP); ISSUE 5 - insufficient knowledge of ABC among employees; ISSUE 6 - difficulty with model construction (i.e. selection of activities); ISSUE 7 - lack of adequate IT resources.

The weighting of individual problems was similar in Poland and Lithuania. Statistically significant differences were noted only for the lack of management support. Enterprises in Poland perceived this problem as lower (mean: 2.5) than in Lithuania (mean: 3.1).
In order to determine the significance of the differences in the approach to implementing $\mathrm{ABC}$ from particular groups of companies, the U Mann-Whitney test was used. Some statistically significant $(\alpha=0.05)$ differences based on the developed indices between groups were found (Table 6).

Statistical Results of the U Mann-Whitney Test for IND $_{\mathbf{X}}$

Table 6

\begin{tabular}{|c|c|c|c|c|}
\hline & Group & $\begin{array}{c}\text { B - companies considering } \\
\text { ABC use }\end{array}$ & $\begin{array}{c}\mathrm{C} \text { - companies which had not } \\
\text { considered ABC use }\end{array}$ & $\begin{array}{c}\text { D - companies which rejected } \\
\text { ABC }\end{array}$ \\
\hline A & companies using $\mathrm{ABC}$ & $\begin{array}{c}\mathrm{Z}:-2.83747^{*} \\
\text { p: } 0.004548\end{array}$ & $\begin{array}{c}\mathrm{Z}:-3.54878^{*} \\
\text { p: } 0.000387\end{array}$ & $\begin{array}{c}\text { Z: }-3.48891^{*} \\
\text { p: } 0.000485\end{array}$ \\
\hline B & companies considering $\mathrm{ABC}$ use & & $\begin{array}{l}\text { Z: }-0.880976 \\
\text { p: } 0.378331\end{array}$ & $\begin{array}{l}\mathrm{Z}:-2.21659^{*} \\
\text { p: } 0.026652\end{array}$ \\
\hline $\mathrm{C}$ & $\begin{array}{l}\text { companies which had not } \\
\text { considered } \mathrm{ABC} \text { use }\end{array}$ & & & $\begin{array}{l}\mathrm{Z}: 1.420819 \\
\text { p: } 0.155370\end{array}$ \\
\hline
\end{tabular}

*statistically significant differences $(\alpha=0.05)$. 
The analysis showed that there are differences in the perception of problems of implementing $\mathrm{ABC}$ between companies that have already implemented an $\mathrm{ABC}$ system and the other groups of companies. The problems with $\mathrm{ABC}$ implementation seen by companies using the system were considerably smaller than the other groups. A similar difference was noted between enterprises that were considering the system and those that had rejected it. The last group (companies that had rejected $\mathrm{ABC}$ ) perceived implementation problems to be bigger than was the case in the group which was still considering it. Additional analysis of the influence of company size, type of main operation, origin of capital, etc., on perceived problems with $\mathrm{ABC}$ implementation revealed no significant correlations.

\section{Discussion}

The conducted research was an attempt to examine problems with $\mathrm{ABC}$ implementation in Lithuanian and Polish companies while applying general economic principles in this analysis (Valanciene \& Gimzauskiene, 2007; Strumickas \& Valanciene, 2009). Focusing on the behavior of an organizations in making decision concerning application of costing system seems especially important from a microeconomic point of view. Addressing the scientific problem, the research provides empirical evidence on the problems with $\mathrm{ABC}$ implementation in companies using the system, considering its implementation or not considering it or those which rejected implementation.

Our findings seem to be in line with rational decision making by the management. When a company encounters problems related to $\mathrm{ABC}$ implementation that are too significant, it stops the implementation process. However, when the problems are perceived as small, it tries to overcome them and continues with the process. Examining the different barriers to $\mathrm{ABC}$ implementation shows that the decision about using $\mathrm{ABC}$ is complex. Managers making such a decision should be aware of how different problems could affect the success of the implementation. This research may provide recommendations both for companies which are using the system and for those considering its application.

Firstly, companies considering $\mathrm{ABC}$ implementation should try to overcome problems that occur during the implementation process, and in particular they should: (a) ensure management support (especially top management), (b) provide sufficient resources both for the implementation itself and maintenance of the system, (c) acquire and spread knowledge about ABC among managers, (d) communicate the aims of the implementation in a clear way, (e) establish a cross-functional implementation team, (f) plan the implementation well and approximately outline its range, (g) avoid implementing $\mathrm{ABC}$ models that are too complex, (h) fully integrate $\mathrm{ABC}$ with the existing IT infrastructure, and (i) deliver the results quickly.

Secondly, companies which are already using ABC should remember that there are modifications which can adapt the system to the changing environment. What is more, managers should understand that $\mathrm{ABC}$ use does not directly improve the financial results or the competitiveness of the company. This is only possible when the information provided by the system is used by managers to make appropriate operational and strategic decisions.

Thirdly, it should be borne in mind that ABC should not be implemented in all companies. Adopting $\mathrm{ABC}$ in many companies may not provide significantly better results than traditional cost accounting systems in such areas as timesaving or labor input. Such an interpretation complies with Chenhall \& Langfield-Smith's (1998) conclusions. They suggested that benefits resulting from the implementation of modern management accounting methods still do not outweigh the benefits resulting from the use of traditional methods. Such an interpretation also explains the behavior of companies which began implementing the innovation but, at some point, abandoned it (Innes \& Mitchell, 1991). It seems from the research that the benefits that $\mathrm{ABC}$ can bring to some companies are not great enough to warrant its implementation, on the one hand, and on the other hand, the barriers to implementation are so high that the implementation should be rejected or at least postponed.

\section{Conclusions}

The conducted study has both theoretical and practical significance. From the theoretical point of view, the research examined perceived problems with $\mathrm{ABC}$ implementation in four different clusters of the companies i.e. companies which: (a) implemented ABC, (b) were considering implementation, (c) were not considering implementation and (d) rejected implementation. What is more, the research showed significant differences in perceived problems with $\mathrm{ABC}$ implementation in the above four clusters of the companies, proving rationality in decision making by managers as $\mathrm{ABC}$ implementation is concerned. It also provided a detailed examination of problems perceived in $\mathrm{ABC}$ implementation of companies in two European countries, Poland and Lithuania. To the best of the authors' knowledge, such an extensive study has never been performed in these countries before. The research has also relevance for practitioners which could use its results to assess the magnitude of problems which they expect during ABC implementation - this could potentially help them make the right decision about whether to proceed with the implementation or not.

What is more, the research provides a starting point for further examination of $\mathrm{ABC}$ barriers from the point of view of companies which use the system, those which are considering (or not considering) its future implementation, and also those which rejected the implementation. Both quantitative and qualitative methods could be used in such studies. From a practical point of view, the research showed that companies considering $\mathrm{ABC}$ implementation should be aware of the problems which might occur during the application process. Also, managers could use the study results to assess the problems which they expect during implementation; this could potentially help them make the right decision about whether to proceed with the implementation or not. The last issue which comes from the research is its usefulness in identifying barriers in ABC implementation which should be addressed in teaching of management accounting. 
Zaneta Pietrzak, Tomasz Wnuk-Pel, Ceslovas Christauskas. Problems with Activity-Based Costing Implementation in ...

It should be stressed that the research results cannot constitute a complete source of knowledge on problems and barriers towards ABC implementation. Firstly, the sample that was used is not representative; thus, it cannot be seen as the basis for examining the practice in all companies operating in Poland and Lithuania, especially as we concentrated only on medium, large, and very large enterprises. Secondly, there are well-known limitations of questionnaire research itself which must be taken into consideration. Those limitations open possible future directions of research with the use of, e.g., qualitative methods, which would enable a more detailed examination of the problems and a better understanding of the barriers towards $\mathrm{ABC}$ implementation.

\section{Appendix 1}

The questionnaire. Problems with Activity-Based Costing implementation in Polish and Lithuanian companies

\section{COMPANY CHARACTERISTICS}

1.1. Sector:

\begin{tabular}{|c|c|c|c|c|}
\hline private company & public company & & & \\
\hline 0 & 1 & & & \\
\hline \multicolumn{2}{|c|}{ 1.2. Type of main operation: } & & & \\
\hline non-manufacturing & manufacturing & & & \\
\hline $\begin{array}{r}0 \\
\end{array}$ & 1 & & & \\
\hline \multicolumn{2}{|l|}{ 1.3. Origin of capital: } & & & \\
\hline $100 \%$ domestic & share of foreign & & & \\
\hline $\begin{array}{c}0 \\
\end{array}$ & 1 & & & \\
\hline \multicolumn{5}{|l|}{ 1.4. Employees: } \\
\hline $\begin{array}{r}<10 \\
\end{array}$ & $11-50$ & $51-250$ & $251-1.000$ & $>1.000$ \\
\hline $\begin{array}{r}1 \\
\end{array}$ & 2 & 3 & 4 & 5 \\
\hline \multicolumn{5}{|c|}{ 1.5. Annual turnover/revenue (for 2014): } \\
\hline$<2$ million $€$ & $2-10$ million $€$ & $11-50$ million $€$ & $50-200$ million $€$ & $>200$ million $€$ \\
\hline \begin{tabular}{|c|}
1 \\
\end{tabular} & 2 & 3 & 4 & 5 \\
\hline \multicolumn{5}{|c|}{ 1.6. Total assets (end of 2014): } \\
\hline$<2$ million $€$ & 2-10 million $€$ & $11-43$ million $€$ & 43-200 million $€$ & $>200$ million $€$ \\
\hline 1 & 2 & 3 & 4 & 5 \\
\hline
\end{tabular}

\section{CHIEF FINANCIAL OFFICER CHARACTERISTICS}

\subsection{Chief Financial Officer's age:}

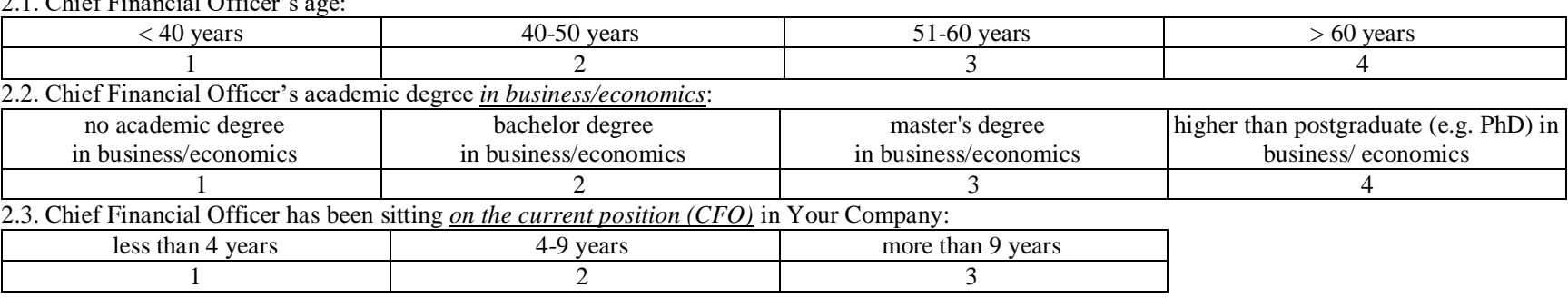

\section{GENERAL INFORMATION ABOUT COMPANY'S COSTING SYSTEM}

3.1. By whom was the shape of Your company's costing system decided:

a. virtually independently by the company's management,

b. partly by company's management and partly by the headquarter (i.e. the parent company),

c. almost entirely by the headquarter (i.e. the parent company),

d. others, please explain.

3.2. How long ago in Your company current costing system has been implemented:

\begin{tabular}{|c|c|c|}
\hline $1-3$ years & $4-10$ years & more than 10 years \\
\hline 1 & 2 & 3 \\
\hline
\end{tabular}

3.3. What is the share of indirect costs in Your company:

\begin{tabular}{|c|c|c|c|c|}
\hline $0-10 \%$ & $11-20 \%$ & $21-30 \%$ & $31-40 \%$ & more than $40 \%$ \\
\hline 1 & 2 & 3 & 5 \\
\hline
\end{tabular}

3.4. In the last 10 years the share of indirect costs in total costs in Your company:

\begin{tabular}{|c|c|c|c|}
\hline 3.4. In the last 10 years the share of indirect costs in total costs in Your company: & $\begin{array}{c}\text { increased substantially } \\
(\text { more than } 5 \%)\end{array}$ \\
\hline 1 & 2 & $\begin{array}{c}\text { increased slightly } \\
(0-5 \%)\end{array}$ & 4 \\
\hline
\end{tabular}

\section{COMPANY'S ATTITUDE TOWARDS ABC}

4.1. Do Your company currently:

a. is using ABC system (please fill in questions 4.2 and 4.3 only),

b. is considering implementation of $\mathrm{ABC}$ in the future (please fill in question 4.4 only),

c. has examined the possibility of $\mathrm{ABC}$ implementation and rejected it (please fill in question 4.5 only),

d. not yet considered the implementation of $\mathrm{ABC}$ (please fill in question 4.5 only).

4.2. If Your company is using $A B C$, what influenced its implementation: 
Inzinerine Ekonomika-Engineering Economics, 2020, 31(1), 26-38

\begin{tabular}{|c|c|c|c|c|c|}
\hline & $\begin{array}{c}\text { no } \\
\text { influence }\end{array}$ & $\begin{array}{c}\text { little } \\
\text { influence }\end{array}$ & $\begin{array}{l}\text { moderate } \\
\text { influence }\end{array}$ & $\begin{array}{l}\text { significant } \\
\text { influence }\end{array}$ & $\begin{array}{c}\text { very } \\
\text { significant influence }\end{array}$ \\
\hline headquarters' demands (i.e. parent company) & 1 & 2 & 3 & 4 & 5 \\
\hline increased competition & 1 & 2 & 3 & 4 & 5 \\
\hline dissatisfaction with existing cost system & 1 & 2 & 3 & 4 & 5 \\
\hline changed management information needs & 1 & 2 & 3 & 4 & 5 \\
\hline change in organizational structure & 1 & 2 & 3 & 4 & 5 \\
\hline change of management & 1 & 2 & 3 & 4 & 5 \\
\hline change of strategy & 1 & 2 & 3 & 4 & 5 \\
\hline implementation of new technologies & 1 & 2 & 3 & 4 & 5 \\
\hline need for cost reduction and performance improvement & 1 & 2 & 3 & 4 & 5 \\
\hline desire to gain new markets & 1 & 2 & 3 & 4 & 5 \\
\hline need for improvement of control & 1 & 2 & 3 & 4 & 5 \\
\hline favorable attitude among employees & 1 & 2 & 3 & 4 & 5 \\
\hline availability of financial resources & 1 & 2 & 3 & 4 & 5 \\
\hline availability of human resources & 1 & 2 & 3 & 4 & 5 \\
\hline 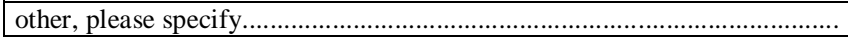 & 1 & 2 & 3 & 4 & 5 \\
\hline \multicolumn{6}{|c|}{ 4.3. If Your company is using $A B C$, what were the main problems during the implementation: } \\
\hline & $\begin{array}{c}\text { no } \\
\text { problem }\end{array}$ & $\begin{array}{c}\text { little } \\
\text { problem }\end{array}$ & $\begin{array}{l}\text { moderate } \\
\text { problem }\end{array}$ & $\begin{array}{l}\text { significant } \\
\text { problem }\end{array}$ & $\begin{array}{c}\text { very } \\
\text { significant problem }\end{array}$ \\
\hline lack of management support & 1 & 2 & 3 & 4 & 5 \\
\hline high cost of $\mathrm{ABC}$ implementation and operation & 1 & 2 & 3 & 4 & 5 \\
\hline high labor input in ABC implementation and operation & 1 & 2 & 3 & 4 & 5 \\
\hline other priorities (e.g. implementation of ISO, ERP) & 1 & 2 & 3 & 4 & 5 \\
\hline insufficient knowledge of $\mathrm{ABC}$ among employees & 1 & 2 & 3 & 4 & 5 \\
\hline difficulty with model construction (i.e. activities selection) & 1 & 2 & 3 & 4 & 5 \\
\hline lack of adequate IT resources & 1 & 2 & 3 & 4 & 5 \\
\hline 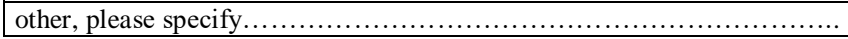 & 1 & 2 & 3 & 4 & 5 \\
\hline \multicolumn{6}{|c|}{ 4.4. If Your company is considering implementation of $A B C$ in the future, what are the main problems it expect during the implementation: } \\
\hline & $\begin{array}{c}\text { no } \\
\text { problem }\end{array}$ & $\begin{array}{c}\text { little } \\
\text { problem }\end{array}$ & $\begin{array}{c}\text { moderate } \\
\text { problem }\end{array}$ & $\begin{array}{c}\text { significant } \\
\text { problem }\end{array}$ & $\begin{array}{c}\text { very } \\
\text { significant problem } \\
\end{array}$ \\
\hline lack of management support & 1 & 2 & 3 & 4 & 5 \\
\hline high cost of $\mathrm{ABC}$ implementation and operation & 1 & 2 & 3 & 4 & 5 \\
\hline high labor input in $\mathrm{ABC}$ implementation and operation & 1 & 2 & 3 & 4 & 5 \\
\hline other priorities (e.g. implementation of ISO, ERP) & 1 & 2 & 3 & 4 & 5 \\
\hline insufficient knowledge of $\mathrm{ABC}$ among employees & 1 & 2 & 3 & 4 & 5 \\
\hline difficulty with model construction (i.e. activities selection) & 1 & 2 & 3 & 4 & 5 \\
\hline lack of adequate IT resources & 1 & 2 & 3 & 4 & 5 \\
\hline 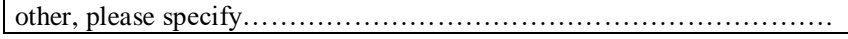 & 1 & 2 & 3 & 4 & 5 \\
\hline \multicolumn{6}{|c|}{ 4.5. If Your company has not considered ABC implementation or rejected it, what were the reasons: } \\
\hline & \begin{tabular}{c|c} 
no \\
importance
\end{tabular} & $\begin{array}{c}\text { little } \\
\text { importance }\end{array}$ & $\begin{array}{c}\text { moderate } \\
\text { importance }\end{array}$ & $\begin{array}{l}\text { significant } \\
\text { importance }\end{array}$ & $\begin{array}{c}\text { very } \\
\text { significant importance }\end{array}$ \\
\hline satisfaction with existing cost system & 1 & 2 & 3 & 4 & 5 \\
\hline low levels of indirect costs & 1 & 2 & 3 & 4 & 5 \\
\hline lack of management support & 1 & 2 & 3 & 4 & 5 \\
\hline high cost of $\mathrm{ABC}$ implementation and operation & 1 & 2 & 3 & 4 & 5 \\
\hline high labor input in $\mathrm{ABC}$ implementation and operation & 1 & 2 & 3 & 4 & 5 \\
\hline other priorities (e.g. implementation of ISO, ERP) & 1 & 2 & 3 & 4 & 5 \\
\hline insufficient knowledge of $\mathrm{ABC}$ among employees & 1 & 2 & 3 & 4 & 5 \\
\hline difficulty with model construction (i.e. activities selection) & 1 & 2 & 3 & 4 & 5 \\
\hline lack of adequate IT resources & 1 & 2 & 3 & 4 & 5 \\
\hline other, please specify............... & 1 & 2 & 3 & 4 & 5 \\
\hline
\end{tabular}

\section{References}

Akyol, D. E., Tuncel, G., \& Bayhan, G.M. (2005). A comparative analysis of activity-based costing and traditional costing. International Journal of Industrial and Manufacturing Engineering, 1(3), 136-139.

Allain, E., \& Laurin, C. (2018). Explaining implementation difficulties associated with Activity-Based Costing through systems use. Journal of Applied Accounting Research, 19(1), 181-198. https://doi.org/10.1108/JAAR-11-2014-0120

Almeida, A., \& Cunha, J. (2017). The implementation of an Activity-Based Costing (ABC) system in a manufacturing company. Procedia manufacturing, 13, 932-939. https://doi.org/10.1016/j.promfg.2017.09.162

Altawati, N. O. M. T., Kim-Soon, N., Ahmad, A. R., \& Elmabrok, A. A. (2018). A Review of Traditional Cost System versus Activity Based Costing Approaches. Advanced Science Letters, 24(6), 4688-4694. https://doi.org/10.1166/asl. 2018.11682

Anderson, S., \& Young, S. (1999). The Impact of Contextual and Process Factors on the Evaluation of Activity-Based Costing Systems. Accounting, Organizations and Society, 24(7), 525-559. https://doi.org/10.1016/S0361-3682 (99)00018-5 
Zaneta Pietrzak, Tomasz Wnuk-Pel, Ceslovas Christauskas. Problems with Activity-Based Costing Implementation in ...

Arora, A. K., \& Raju, M. S. S (2018). An analysis of activity based costing practices in selected manufacturing units in India, Indian Journal of Finance, 12(12), December 2018, Pages 22-31. https://doi.org/10.17010/ijf/2018/v12i12/139889

Askarany, D., \& Yazdifar, H. (2007). Why ABC is Not Widely Implemented? International Journal of Business Research, 7(1), 93-98. https://doi.org/10.1504/IJBSR.2007.014776

Askarany, D., Smith, M., \& Yazdifar, H. (2007). Technological Innovations, Activity Based Costing and Satisfaction. Journal of Accounting - Business \& Management, 14, 53-63.

Bescos, P. L., Cauvin, E., \& Gosselin, M. (2002). Activity-Based Costing and Activity-Based Management: Comparison of the Practices in Canada and in France. Compatabilite, controle et audit, 8, 229-244. https://doi.org/10.3917/ cca.083.0229

Chenhall, R., \& Langfield-Smith, K. (1998). Adoption and benefits of management accounting practices: an Australian study. Management Accounting Research, 9(1), 1-19. https://doi.org/10.1006/mare.1997.0060

Clarke, F., Dean, G., Lowry, J., \& Wells, M. (1997). Financial and Management Accounting in Australia. In N. Baydoun, A. Nishimura, \& R. Willet (Eds.), Accounting in the Asia- Pacific Region (121-148). New York: John Wiley \& Sons.

Clarke, P. J., \& Mullins, T. (2001). Activity Based Costing in the Non-Manufacturing Sector in Ireland: A Preliminary Investigation. The Irish Journal of Management, 22(2), 1-18.

Cohen, S., Venieris, G., \& Kaimenaki, E. (2005). ABC: Adopters, Supporters, Deniers and Unawares. Managerial Auditing Journal, 20(9), 981-1000. https://doi.org/10.1108/02686900510625325

Cooper, R., \& Kaplan, R. S. (1988). Measure Costs Right: Make Right Decision. Harvard Business Review, SeptemberOctober, 96-103.

Daly, D. C., \& Freeman, T. (1997). The Road to Excellence. Becoming a process-based Company. CAM-I 1997.

Dragija, M., \& Lutilsky, I. D. (2012). Activity based costing as a means to full costing - possibilities and constraints for European universities. Management, 17(1), 33-57.

Dynowska, J., \& Cyganska, M. (2010). Stopien wdrozenia rachunku kosztow dzialan w przedsiębiorstwach wojewodztwa warminsko-mazurskiego w swietle badania ankietowego. Zeszyty Teoretyczne Rachunkowosci, 58, 85-98.

ElGammal, W., Zakka, J. S., El-Kassar, A. N., \& Dandash, G. (2016). Reasons behind the non-application of the activity based costing system in developing countries, case of Lebanon. The Journal of Developing Areas, 50(3), 417-435. https://doi.org/10.1353/jda.2016.0109

Feng, S., \& Ho, C. Y. (2016). The real option approach to adoption or discontinuation of a management accounting innovation: the case of activity-based costing. Review of Quantitative Finance and Accounting, 47(3), 835-856. https://doi.org/10.1007/s11156-015-0522-4

Gimzauskiene, E., \& Kloviene, L. (2008). Implementing Activity Based Management: the Role of Organizational Values. Social Research, 4(14), 26-35.

Gliaubicas, D., \& Kanapickiene, R. (2015). Contingencies impact on strategic cost management usage in Lithuanian companies. Procedia-Social and Behavioral Sciences, 213, 254-260. https://doi.org/10.1016/j.sbspro.2015.11.534

Groot, T. L. C. M. (1999). Activity-Based Costing in U.S. and Dutch Food Companies. Advances in Management Accounting, 7, 47-63.

Hasan, A. (2017). Implementation Problems of Activity Based Costing: A Study of Companies in Jordan. British Journal of Economics, Management and Trade, 17(1), 1-9. https://doi.org/10.9734/BJEMT/2017/32855

Horngren, Ch. T., Foster, G., \& Datar, S. M. (2000). Cost Accounting, Managerial Emphasis. New York: Prentice-Hall International.

Hudakova, S. L., \& Bajus, R. (2015). Cost management using activity-based costing model. Актуальні проблеми економіки, (2), 373-386.

Innes, J., \& Mitchell, F. (1991). ABC: a Survey of CIMA Members. Management Accounting (UK), 69, 28 -30.

Innes, J., \& Mitchell, F. (1995). A Survey of Activity-Based Costing in the U.K.'s Largest Companies. Management Accounting Research, 6, 137-153. https://doi.org/10.1006/mare.1995.1008

Januszewski, A., \& Gierusz, J. (2004). Mozliwosci wdrozenia rachunku kosztow dzialan - wyniki badan empirycznych. Rachunkowosc, 7, 19-23.

Jinga, G., Dumitru, M., Dumitrana, M., \& Vulpoi, M. (2010). Accounting systems for cost management used in the Romanian economic entities. Accounting and Management Information Systems, 9(2), 242-267.

Joseph, C. S., \& Piorce, V. R. M. (2019 May).Factors Influencing Non-Adoption of Activity Based Costing in Small and Medium Enterprises in the Technological Era: An Empirical Investigation among Indian Firms. International Journal of Recent Technology and Engineering, 8(1), 3235-3241. 
Kujacic, M., Blagojevic, M., Sarac, D., \& Vesovic, V. (2015). The modified activity-based costing method in universal postal service area: Case study of the montenegro post. Inzinerine Ekonomika-Engineering Economics, 26(2), 142151. https://doi.org/10.5755/j01.ee.26.2.2818

Lu, C., Sridharan, V. G., \& Tse, M. S. (2016). Implementation of the activity-based costing model for a farm: an Australian case. Journal of Applied Management Accounting Research, 14(2).

Miodek, W., \& Wnuk-Pel, T. (2017). Barriers of Activity-Based Costing Implementation in Polish Companies. Lodz: Wydawnictwo Uniwersytetu Lodzkiego.

Novak, P., \& Popesko, B. (2008). Activity-Based Costing applications in the Czech Republic. Lex ET Scientia International, 15(1), 69-75.

Pierce, B., \& Brown, R. (2004). An empirical study of activity-based systems in Ireland, The Irish Accounting Review, 11(1), 33-55.

Quinn, M., Elafi, O., \& Mulgrew, M. (2017). Reasons for not changing to activity-based costing: a survey of Irish firms. PSU Research Review, 1(1), 63-70. https://doi.org/10.1108/PRR-12-2016-0017

Rundora, R., \& Selesho, J. (2014). Determinants and Barriers to the Adoption of Activity-Based Costing for Manufacturing SMEs in South Africa's Emfuleni Municipality. Mediterranean Journal of Social Sciences, 5(3), 30-35. https://doi.org/10.5901/mjss.2014.v5n3p30

Sartorius, K., Eitzen, C., \& Kamala, P. (2007). The Design and Implementation of Activity-Based Costing (ABC): A South African Survey. Meditari Accountancy Research, 15(2), 1-21. https://doi.org/10.1108/10222529200700008

Sobanska, I., \& Wnuk, T. (2000). Causes and Directions of Changes in Management Accounting Practice in Poland. Paper presented at the Conference on Economics \& Management: Actualities and Methodology. Kaunas.

Sorros, J., Karagiorgos, A., \& Mpelesis, N. (2017). Adoption of Activity-Based Costing: A Survey of the Education Sector of Greece. International Advances in Economic Research, 23(3), 309-320. https://doi.org/10.1007/s11294-017-9640-1

Strumickas, M., \& Valanciene, L. (2009). Research of management accounting changes in Lithuanian business organizations. Inzinerine Ekonomika-Engineering Economics, (3), 26-32.

Szychta, A. (2002). The Scope and Application of Management Accounting Methods in Polish Enterprises. Management Accounting Research, 13(4), 401-418. https://doi.org/10.1006/mare.2002.0198

Valanciene, L., \& Gimzauskiene, E. (2007). Changing role of management accounting: Lithuanian Experience case studies. Inzinerine Ekonomika-Engineering Economics(5), 16-23.

Wahab, A. B. A., Mohamad, M. H. S., \& Said, J. M. (2018). The Implementation of Activity-based Costing in the Accountant General's Department of Malaysia. Asian Journal of Accounting and Governance, 9, 63-76. https://doi.org/10.17576/AJAG-2018-09-06

Wegmann, G. (2011). The development of the Activity-Based Costing method: A comparison between France and China, University of Burgundy - IAE Dijon School of Management, CREGO EA 7317, 6 May. https://doi.org/10.21 39/ssrn. 1858718

Wegmann, G. (2019). A typology of cost accounting practices based on Activity-Based Costing-a strategic cost management approach. Asia-Pacific Management Accounting Journal, 14(2), 161-184. https://doi.org/10.2139/ssrn. 3236159

Wnuk-Pel, T. (2011). Zastosowanie rachunku kosztow dzialan w przedsiebiorstwach w Polsce. Lodz: WUL.

Zikmund, W. G., McLeod, R., \& Gilbert, F. W. (2003). Customer relationship management: Integrating marketing strategy and information technology. New York: John Wiley and Sons.

The article has been reviewed.

Received in October 2019; accepted in February 2020. 